\title{
İlhan Tekeli'nin Fikriyatında Temsili Demokrasinin Krizine Bir Yanıt Olarak Sivil Toplum Kuruluşları ve Yerel Yönetimler
}

\author{
Hülya Eşki Uğuz ${ }^{1}$ \\ ORCID: 0000-0003-1583-0501
}

\author{
Firat Harun Y1lmaz ${ }^{2}$ \\ ORCID: 0000-0003-2838-5400
}

Öz

Temsili demokrasinin modernite projesinden ve ulus devletin temel toplumsal birim olmasindan kaynaklanan dayanaklarının hızla aşındiğı günümüzde temsili demokrasilerin kendi meşruiyetlerinin yanı sıra katılımo demokrasi pratiklerine yer açmak zorunda kalması Tekeli'yi, bu iki demokrasi anlayışının iç içe nasıl var olabileceği sorusu üzerine düşünmeye zorlar. Bu aslında demokrasilerin nasıl daha demokratik kılınabileceğine ilişkin bir soru olup, onun çalışmalarında soru iki farklı düzlemde yanıt bulur. Düzlemlerin ilkinde karşımıza çıkan sivil toplum kuruluşlarıdır ve ona göre STK'ların kamu alanındaki etkinliği artırılarak STK'lara yaşamı zenginleştirme, çoğulculuğu gerçekleştirme, bireylere kamusal özne olma yolunu açma olanağı să̆lanmalıdır. Diğer düzlemde ise bireyin var olduğu alanlar olarak bu rol yerele biçilir ve onun anlatısında yerel, temsili demokrasinin katılımo demokrasi ile bütünleşebilmesinin en iyi araçlarından birisine dönüşür. Büyük ölçüde onun düşünceleri etrafinda şekillenen bu çalışmada STK'lar, Tekeli'nin yaptığı gibi farklı noktalardan hareketle kuşatılmaya çalışılmıştır. Öncelikle STK'lara temsili demokrasinin yetersiz kalmasından ve katılımo demokrasi kavramının gelişiminden hareketle ulaşılmaya çalışılmıştır. Öte taraftan onun işaret ettiği üzere demokrasilerin performansının katılımcılıkla doyurucu hale gelmesinde en iyi uygulama ölçeği olarak yerel yönetimler üzerinde durulmuştur.

Anahtar Kelimeler: Temsili demokrasi, kriz, sivil toplum kuruluşları, katılımo demokrasi, yerel yönetimler.

\footnotetext{
${ }^{1}$ Prof. Dr., Selçuk Üniversitesi, E-mail: hukyaeski@selcuk.edu.tr

${ }^{2}$ Arş. Gör., Selçuk Üniversitesi E-mail: firatyilmaz@selcuk.edu.tr

idealkent (c) Kent Araştırmaları Dergisi (Journal of Urban Studies) 


\title{
Civil Society Organizations and Local Governments as a Response to Crisis of Representative Democracy within the Thoughts of İlhan Tekeli
}

\author{
Hülya Eşki Uğuz 3 \\ ORCID: 0000-0003-1583-0501
}

\author{
Frrat Harun Yilmaz 4 \\ ORCID: 0000-0003-2838-5400
}

\begin{abstract}
The foundations of representative democracy derived from the modernity project and the nation-state as the basic social unit are eroded today. The obligation of representative democracy to make room for participatory democracy practices besides its legitimacy forced Tekeli to think about how these two understandings of democracy can exist intertwined. This is a question of how democracies can be made more democratic and in his works; the question is answered on two different levels. At the first level, civil society organizations (CSOs) step forward and according to him, by enhancing the effectiveness of CSOs in the public sphere, the opportunity to enrich life, to realize pluralism and to open the way for individuals to become public subject should be given to CSOs. At another level, the role of existence place for individuals is assigned to local and in his understanding, local becomes one of the best means to integrate representative democracy with participatory democracy. Largely constructed around his thoughts, in this study, CSOs were addressed from different viewpoints as Tekeli did. At the outset, it was tried to reach out to the CSOs through the inefficacy of representative democracy and the development of participatory democracy. On the other side, as he points out, local governments were emphasized as the best practice level in making the performance of democracies satisfactory with participation.
\end{abstract}

Keywords: Representative democracy, crisis, civil society organizations, participatory democracy, local governments.

\footnotetext{
${ }^{3}$ Prof. Dr., Selçuk University, E-mail: hukyaeski@selcuk.edu.tr

${ }^{4}$ R. A., Selçuk University, E-mail: firatyilmaz@selcuk.edu.tr

idealkent @ Kent Araştırmaları Dergisi (Journal of Urban Studies) 


\section{Giriş}

Bu çalışma, şehir ve bölge planlama, planlama teorisi, göç ve siyasi davranış, Türkiye'de yerel yönetimler teorisi ve tarihi, kentleşme ve kentsel politika, ekonomi politikası, Türkiye'nin ekonomi tarihi, kent ve toplum tarihi gibi alanlarda pek çok eser vermiş, çok yönlü bir bilim insanı olan İlhan Tekeli'nin demokrasi, sivil toplum kuruluşları ve yerel yönetimler üzerine olan düşüncelerinin bir analizini içermektedir. Klasik liberal demokrasinin temsile dayanan siyaset yapma biçiminin yeni toplumun ihtiyaçlarına ve karmaşık siyasal yaşamına yanıt vermekte zorlandığı şeklindeki bir gerçeklikten hareketle Tekeli, farklı yazılarında (1997, 1999, 2000, 2002, 2004a, 2007, 2009a, 2009b, 2009c, 2009d, 2010, 2011) temsili demokrasinin içine girdiği krize yant üretmenin yollarını aramaktadır. Ona göre demokrasileri daha demokratik kılacak olan; "katılımcı demokrasi", "aktif yurttaş" "sivil inisiyatif", "sivil toplum kuruluşları" ve "yerel yönetimler" dir. Tekeli, demokrasinin bundan sonraki seyri ve salahiyeti adına, "yeni zamanların toplumsal özneleri" olarak bizleri, büyük bir heyecanla bu kavramlar üzerinde birlikte düşünmeye ve tartışmaya davet eder. Bu davete cevaben büyük ölçüde onun düşünceleri etrafında şekillenen bu çalışmada sivil toplum kuruluşları, Tekeli'nin yaptığı gibi farklı noktalardan hareketle kuşatılmaya çalışılacak, öncelikle STK'lara temsili demokrasinin yetersizliği ile katılımc demokrasinin gelişiminden hareketle ulaşılmaya çalışılacaktır. Öte taraftan da demokrasilerin performansı katılımcılıkla doyurucu hale gelecekse bunun en iyi uygulanacağı ölçek olarak onun doğrudan varlığımızla ilişkili gördüğü/var olduğumuz yerel üzerinde durulacaktir.

Sivil toplumun ve STK'ların teorik çerçevesini başarı ile çizen çalışmaları üzerinden yapılacak bir okuma bir taraftan sivil toplum alanının diğer taraftan da yerelin siyaset tarafından ne denli işgal edildiğini görmemize yardımcı olacaktır. Demokrasi ve yerel yönetimler üzerine kaleme aldıkları ise ancak her iki alanın, siyasetin ahlakından uzaklaşarak kendi doğalarına kavuşmaları halinde demokrasinin gerçek anlamda vücut bulabileceğini görebilme adına ufuk açıcı bir deneyim sunacaktır bizlere.

\section{Temsili Demokrasinin Krizi, Katılımcı Demokrasi ve STK'lar}

Tekeli'nin bir modernite projesi olarak değerlendirdiği temsili demokrasiler, günümüzde büyük ölçüde ulus devletin alansal denetiminin anlamını yitir- 
mesinden dolayı bir krizle karşı karşıya olup; insan toplulukları ile bu toplulukların üzerinde yaşadıkları toprak arasındaki sıkı ilişkinin aşınması toplulukların temsilinin yeni bir biçimini zorunlu hale getirmiştir. Temsili anlamlı kılan, sınırları çizilmiş bir toprak parçası ve kendilerini bu alanla tanımlayan bir topluluktur. Bu topluluğun kaderini yalnızca bu sınırlar dâhilinde alınan kararlar belirleyecektir. Ancak yazara göre böyle içe kapalı bir toplum varsayımı geçerli bulunmuyorsa dahi en azından siyasi iktidarın, sınırlarının geçişkenliğini denetleyebildiğini kabul etmek gerekir. Sınırların geçişkenliğinin artması sabit sınırlarla çevrilmiş bir toplumdan söz etme imkânını ortadan kaldırdığı içindir ki temsili demokrasinin bu mantıki dayanağı da günümüzde anlamın yitirmiştir (Tekeli, 2004a).

Bizleri bugün temsili demokrasinin bir kriz içerisine girdiği fikrine götüren bir başka husussa Tekeli'ye göre bireye ilişkin temel kabullerdeki değişimde aranmalıdır. Temsili demokrasinin kurgusal mantığı içinde üretici, tüketici ve seçmen olmak üzere başlıca üç kimlikle karşımıza çıkan atomistik özgür bireyler, günümüzde kendilerine biçilen bu rollerle yetinmemektedirler. Toplumda yeni roller talep eden bireyler, siyasi karar alanını yalnızca temsilcilerin eline bırakmak istememekte, yaşam doyumlarını artırmak için kendi projelerini gerçekleştirmeye ve bir kamusal özneye dönüşmeye büyük bir anlam yüklemektedirler. Yine katılımcı demokrasi anlayışı, bireyin değişimi ile birlikte bir başka değişimi de içerir. Artık kamu alanına yeni bir aktör olarak sivil toplum kuruluşları eklenmiştir. Yazara göre, STK'ları kamusal bir aktöre dönüştüren şey bireyin kamusal özne oluşuyla yakından alakalıdır. Temsili demokrasinin kurguladığı kamusal alan, toplumun tümünü kapsayan bir politik alandır ve bu politik alanda siyasi partilerin aralarındaki yarıştan doğan çatışmacı bir mantık egemendir. Yine uzlaşıdan ziyade çatışmanın egemen olduğu bu alanda rakipler birbirlerini yarışın dışında bırakmak için bir mücadele içerisine girmektedirler. Temsili demokrasinin en temel sorunlarından bir tanesi, kamusal alanda özneye dönüşmelerini büyük ölçüde engelleyerek bireyleri adeta özel alanda kalmaya zorlamasıdır. Bir başka deyişle, temsili demokrasilerde bireyin yaşamını anlamlandırarak doyum sağlayan kamusal özne olma hali, siyasete girmeyenlere kapalı bulunmaktadır. Bu manada temsili demokrasilerde, yurttaşlar sadece kimin kamusal özne olacağını belirlemekte, seçimden sonraysa yurttaşlar, bu kamusal öznelerin kararları ile üretilmiş olan kamu hizmetlerini tüketmektedirler. Bir diğer deyişle bu haliyle mevcut sistem, bireye siyasi partilere girmedikçe kamusal özne olma yolunu kapatmanın yanı sıra, bireyi daha ziyade tüketici vasfı ile 
sınırlandırarak özel alanda kalmaya zorlamaktadır. $\mathrm{Bu}$, demokratik toplumlarda aktif yurttaşların bireysel olarak katılım sergileyemeyecekleri anlamına gelmez. Şüphesiz ki bireyler en basit görünümü ile kamusal makamlara soru sorarak, dilekçe vererek katılım sağlayabilecekleri gibi kendilerini kamusal özneye dönüştürecek eylemlerde de bulunabilirler. Bununla birlikte ne denli aktif olursa olsun bireysel katılımın gücü, örgütlü katılımdan daima daha zayıf olacaktır. Bu sebeple kendisini gerçekleştirmek isteyen günümüzün insanı, toplum için bir şeyler yapmak, yani bir kamusal özne olmak amaciyla birleşerek farklı birlikteliklere hayat vermektedir. İş yaşamının değişme ve gelişme biçimi, bireylere işe ayırılanın dışında büyük bir boş alan bırakarak onların kamusal özne olmalarına imkân tanımaktadır (Tekeli, 2000, s.112; 2009a, s.214; 2009b, s.241-242; 2009c, s.319).

Özetle siyasal kamu alanının işleyiş̧inin bireyleri doyurmayışı olmak üzere, yukarıda bahsi geçen nedenlerden dolayı, günümüzde katılımcı demokrasi pratiği içerisinde kamusal alanda siyasal partiler dışında yeni bir aktör olarak STK'lar gün yüzüne çıkmış, toplumda politik alanın yanı sıra STK'lardan oluşan pek çok küçük kamu alanından söz edilmeye başlanmıştır. Gittikçe önem kazanan ve bir demokrasi göstergesi olarak kabul gören kamusal alanın bu yeni aktörleri, yani STK'lar, kamusal alan açısından bir değerlendirmeye tabi tutulduğunda bu kuruluşlar arasında Tekeli bir ayrıma gitmeyi gerekli görmektedir. Buna göre bu birliktelikler içerisinde sivil inisiyatifler en basit ve eşitlikçi olanlardır. Çoğu kere bir gereksinim oluştuğunda kendiliğinden ortaya çıkan bu birlikteliklere katılmanın ya da girişimden ayrılmanın hiçbir kuralı yoktur. Bu birlikteliklerde bir araya gelenler, bir soruna içten ve gönüllü tepki vermekte veyahut da o gereksinimi gidermeye çalışmaktadırlar. Bu anlamda sivil inisiyatifler, STK'ların en katıksız halini temsil etmektedirler. Bu birlikteliklerce gerçekleştirilmek istenilen hizmetler süreklilik kazandığ1 ve mali işleri içerdiği anda sivil inisiyatifler dernekleşerek ya da vakıf formuna dönüşerek kalıcı yapılar halini alırlar. Kurumsallaşan bu aktörlerse, demokrasi bağlamında iki farklı kategoride ele alınabilir. İlk kategoride, politik alanı bir baskı grubu olarak etki altına almaya çalışan ve Tekeli'ce kitle demokratik örgütleri olarak isimlendirilen örgütler yer almaktadır. Temsili demokratik yapılarda bir baskı grubu olarak çalışan bu kuruluşlar, üyelerinin çıkarlarını korumak için oluşmuşlardır. Bu kuruluşlar siyasal çoğulculuğa imkân vererek temsili demokrasilerin bir çoğunluk sultasına dönüşmesini engellemekte, böylece demokratik işleyişi iyileştirmektedirler. Bu örgütler, kendileri bir şeyler yapmaktansa, daha ziyade kendi dışındaki ak- 
törlerin yapmaları gereken şeyleri söylemektedirler. Bu manada kitle demokratik örgütleri olarak isimlendirilen örgütler, politik alanın çatışmacı ve ötekileştirici söylemleri içerisinde sonuç elde etmeye çalışmaktadırlar. Türkiye'de bu kuruluşları STK'lar içinde değerlendirme eğilimi olmakla birlikte, Tekeli yerinde bir tutumla bu iki kuruluşu birbirinden ayırmaktadır. Çünkü ona göre her iki kuruluş da farklı ahlaki temellerde ilişkilerini kurmak zorundadır. Demokratik kitle örgütleri çatışmacı bir alanda, dışlayıcı bir söylemi geliştirirlerken, sivil toplum kuruluşları oydaşma temelli bir ilişkiyi temel alırlar. Bu nedenle farklı ilişki kurma ahlakına sahip bu kuruluşları aynı pota içerisinde değerlendirmek bir hata olduğu gibi bu durum pek çok karışıklığa da sebebiyet verebilmektedir (Tekeli, 2009c, s.319-320).

İkinci grupta yer alan sivil toplum kuruluşlarıysa, katılımcı demokrasi için anlam taşımakta ve alandaki diğer aktörlerin bir şeyler yapmasını beklemektense, oydaşmacı bir ruhla kendi küçük kamusal alanlarında bir araya gelerek kendileri bir şey yapmakta ve bu suretle bir kamusal alan öznesi olmaktadırlar. Tekeli'ye göre böylelikle sivil toplum kuruluşları, birer kısmi kamusal alana dönüşmektedir. Toplumda kaygı ve beklentileri benzer olan birey veya aktörler, bir mesele üzerinde uzlaşıya vardıklarında sorunun çözümü adına bir araya gelmekte, ortaya çıan bu küçük kamu alanında, uzlaşıya vardıkları meseleler adına kaynak, düşünce ve emeklerini bir araya getirerek toplumsal bir meseleye çözüm üretmeye çalışmaktadırlar. Bireyler kendileri için harcayabilecekleri kazançlarını, toplumsal bir iyi adına sarf etmek sureti ile kamusal bir faaliyette bulunmakta, bir diğer deyişle STK'larla bireylere, kamusal mal ve hizmet üretmenin yolları açılmaktadır. Bu gelişmeler bir yandan bireylere STK'lar aracılığıyla "kamusal bir özne" olma ve çeşitlilik taleplerini yaşama geçirebilme olanağı vermekte, diğer taraftan da bireylerin yaşamlarını anlamlı kılma fırsatını beraberinde getirmektedir. Bireyler tüketmenin değil, aynı zamanda toplumsal olana katkıda bulunmanın doyumunu yaşamaktır (Tekeli, 2002, s.22; 2009a, s.213-214; 2009b, s.243-244; 2010, s.191). Bu anlamda sivil toplum, bireyin kendini ait olduğu topluluk içerisinde gerçekleştirmesine, var kılmasına imkân tanıyan bir özgürlük alanına dönüşür ki Tekeli (2010, s.158)'ye göre aslında bu, yaşam kalitesini dıştan verilmişlerin sahipliği ya da tüketim miktarı üzerinden değil, gerçekleştirilenler üzerinden tanımlamakla ilgili bir bakış açısıyla ilgilidir. Bu bakış açısından sivil toplum kuruluşları, insanların kendi yaşamlarında kendilerinin gerçekleştirdikleri bir proje olarak görülmeye başlanırsa, bu projenin başarısının, bireyin eylem alanının genişletilmesine bağlı olduğu sonucuna kolayca varılabilecektir. 


\section{Siyasal İktidar ve STK'lar Arasındaki İlişkinin Doğası Üzerine}

Sivil toplum kuruluşlarını birer kamusal alan olarak gören bu anlayış, siyasal gücü bir uzlaşıya dönüştürür. Bu durumda meşruluğunu temsil mekanizmasından kazanan bir siyasi iktidarla, varlığının geçerliliğini çok sayıdaki küçük kamusal alanlar arasındaki uzlaşıya borçlu olan iki farklı gücün bir arada yaşayacağı bir yapı ortaya çıkar. Bu güç ilişkisinin bir tarafında yer alan STK'lar, kamusal alanın tümünü kapsama iddiasında değildirler. Onların iddiası siyasi iktidarla beraber var olma, alanı zenginleştirme, bu suretle çoğulculuğu yaşama geçirmektir. Bu noktadan hareketle, uzun vadede STK'ların niteliksel ve niceliksel gelişiminin siyasi iktidara duyulan gereksinimi ortadan kaldıracağı söylenemez. Çok sayıda küçük sivil toplum alanı ve bu alanda faaliyette bulunan özneler, şayet bir siyasi kamusal alan ve buna dayanan bir kamu otoritesi yani devlet yoksa, kendilerinden beklenilen işlevleri yerine getiremeyecek ve bir kaos ya da emrivakiler alanı yaratacaktır. Bu sebeple, ancak sivil ve siyasal kamu alanları ile bu alanların öznelerinin bir arada var olması halinde demokrasinin niteliği gelişecek ve daha tatminkâr sonuçlar üretebilecektir (Tekeli, 2009a, s.214; Tekeli, 2009b, s.244; Tekeli, 2009c, s.314).

Tekeli her iki kamusal alanın birlikte var olmasının gerekliliğini ortaya koyduktan sonra, aynı zamanda siyasal ve sivil toplum kamusal alanlarının birbirlerine göre konumları hakkında da önemli çıkarımlarda bulunur. Ona göre siyasal ve sivil toplum kamusal alanlarının ahlaklarının birbirinden farklı olması zorunludur. Politik alanda siyasi gücü ele geçirebilmek ya da etkilemek için partiler, siyasi hareketler, baskı grupları çatışmacı bir ruhla faaliyette bulunmaktadırlar. Bu alan gerilimli, uzlaşıdan ziyade ötekinin karşıtlığında örgütlenme pratiğine dayalı, bu manada da diğerlerini dışlayan bir alandır. Bu durum, söz konusu alanın ele geçirilerek denetlenmek istenilen tekli bir kamu alanı oluşundan kaynaklanmaktadır. Sivil alanınsa çatışmacı bir ahlakla hareket etmesi gerekmemektedir. Bilakis bu alanda güç; uzlaşı ve görüş birliğine varmaktan kaynaklanmaktadır. Bu alanın özneleri, ne suretle olursa olsun kendi düşüncelerini diğerlerine dayatmazlar ve aktörler iknaya açıktırlar. Şüphesiz ki sivil toplum alanında birbiriyle uyuşmayan görüşler de bulunacaktır. Ama bu durum, bu alanın içinde kaçınılmaz olarak bir çatışmanın yaşanacağı anlamına gelmez. Fikirleri birbirinden farklılaşanlar, ötekiyle uzlaşamıyorlarsa kendi kamusal alanlarını oluşturmak sureti ile fikirlerini hayata geçirmeye çalışabilirler. Tekeli'nin son derece yerinde tespitiyle siyasal kamu alanının çatışmacı doğasını, sivil toplumun alanına taşımanın bu alanı doğasından uzaklaştırarak bozacağı burada belirtilmelidir. Yine 
ifade edilmelidir ki siyasal ve sivil kamu alanlarının farklı ahlaklara sahip oluşu bu iki alan arasında bir etkileşimin olmayacağı anlamına gelmez. STK'larda bir araya gelen bireyler, toplumsal bir iyiye katkıda bulunmak için kamu hizmeti sunumuna odaklanabilecekleri gibi amaçlarına ulaşabilmek için siyasi alanla etkileşime de geçebilirler. Bununla beraber bir sivil toplum kuruluşu, siyasi alanda etkin olmaya çalışsa dahi sivil toplumun ahlakından uzaklaşmamalıdır. Bu husus oldukça önemlidir. Sivil toplum kuruluşları alanına siyasal kamu alanının ahlakını taşımak gerekmez (Tekeli, 1997, s.20; 2009a, s.214-215).

Tekeli'nin fikriyatında siyasal ve sivil toplum kamu alanlarının yan yana getirilmesi iki farklı meşruiyet anlayışının toplumda kendilerine yer açmakta yarışması şeklinde değerlendirilir. Temsili demokrasilerle yönetilen devletlerde siyasi güç, meşruiyetini seçim sürecinden almaktadır. Sivil toplum kamu alanında ise gücün kullanımı meşruiyetini görüş birliğinden almaktadır. Bu noktada kurumsallaşmış temsili meşruiyet sistemi yanında yeni bir meşruiyet anlayışının kendisine nasıl yer açacağı sorusu temel bir mesele olarak belirmektedir. Temsil suretiyle siyasi gücü kazananlar, tüm toplum adına söz söyleyebilme iddiasını taşımaktadırlar. Toplumda belirli bir fikir birliğini ve bunun sağladığı gücü ele geçirenler, bu güçten hareketle ötekini dışarıda bırakma hakkına sahip olduğunu düşünebilecektir. Bu durumda küçük kamu alanlarının kendilerini kabul ettirebilmelerinin iki yolu bulunmaktadır. Bunlardan ilki sivil toplum kuruluşlarının işlev alanlarını devletin işlev alanının dışına taşıyarak kendileri için yeni alanlar yaratmasıdır. Bu durumda sivil toplum kuruluşları, temsili demokrasilerde temsil şansı bulamayan alanlara ilişkin faaliyetlerde bulunarak mikro düzeydeki farklılıkların temsil şansı kazanmasına yönelik arayışlara girerler. Bu ilk yolda, temsili sistemle sivil toplum kuruluşları arasındaki ilişkiyi tamamlayıcılık ilişkisi olarak isimlendirmek gerekir (Tekeli, 1997, s.20; 2009a, s.214-215). Bu ilişki biçimi, devletin de sivil toplum kuruluşlarının da farklı meşruiyet noktalarından hareket ederek kamu için hizmet üretme amacını taşımasından kaynaklanan çatışma olasılığını ortadan kaldırabilir. İkinci seçenekteyse STK'larla devlet arasında ortaklıklar kurularak iki farklı meşruiyet temeli bir araya getirilmektedir. Bir ortaklık ilişkisi olarak isimlendirilebilecek bu seçenekte, STK'lar çeşitli hizmetlerin sunumu, hizmete ilişkin politikaların belirlenmesi ve benzeri hususlarda devletle işbirliğine gitmektedir. Ulus devletlerin faaliyetlerini sadece temsili demokrasiden aldıkları meşruiyet içinde gerçekleştirmesi sonucunda ortaya çıkan ve daha çok ortalama talebi karşılayan kamusal hizmetler, literatürde "yurttaş açı̆̆ı" denilen bir açığı da beraberinde getirmektedir. Bu açık 
toplumda yurttaşların beklentilerinin oluşturduğu taleple, temsili demokrasilerde oy çokluğu ile alınan kararlara dayanan arz düzeyi arasındaki farktan kaynaklanmaktadır. Bu açı̆̆ı, demokrasilerin kalitesine ilişkin bir gösterge olarak kabul edersek, arzın devletle STK'lar tarafından birlikte sağlanması durumunda taleple arz arasındaki fark azalacak, demokrasinin kalitesi ise artacaktır (Tekeli, 1997, s.20; 2000, s.112; 2009a, s.214-215). Bir taraftan temsili demokrasi kalıpları içinde üretilen hizmetler, diğer taraftan da sivil toplum kuruluşlarınca üretilen hizmetlerin varlığı, yani iki farklı meşruiyete dayanan kamu hizmetlerinin üretilmesine birlikte yer verilmesi devlet için anlamlı ve gereklidir. Devlet bu ortaklıkların kendi hizmet açıklarını, yenilikçilik eksikliklerini kapatmaya yardımcı olabileceğini düşünebilir. Tüm bunlardan daha önemlisi, çoğulculuğu benimsemiş bir devletin, sivil toplum kuruluşlarıyla ortaklığa çoğulculuğu yaşama geçirmenin bir yolu olarak bakabilecek olmasidır (Tekeli, 2002, s.23).

\section{Yerel Yönetimler, STK'lar ve Siyaset}

Temsili demokrasinin krizi ve bireye ilişkin temel ontolojik kabullerdeki değişim, hem demokrasinin temsili formunun daha iyi çalışmasına imkân verecek düzenlemeleri hem de demokrasi pratiğini daha doyurucu kılacak uygulamaları zorunlu hale getirmektedir. Bu noktada Tekeli, "rasyonel bir tartı̧̧mayı olanaklı hale getiren bir yerel kamu alanının var kılınması", "haklarına sahip çıkan, sorumluluklar üstlenen ve birlikte yaşama kültürünü içine sindiren yurttaşların varlığı", "yerel yönetimlerin STK'larla işbirliği geliştirmeye gönüllü olması" ve "yerel yönetimlerin yetki ve görevlerinin arttırılması" olmak üzere dört farklı öneride bulunmaktadır (Tekeli, 2004b, s.362; 2012, s.171). Temsili demokrasinin katılımcı demokrasiyle bütünleşmesinin en iyi yerelde gerçekleşeceğine inanan Tekeli, bu bağlamda temsili demokrasinin kalitesinin yükseltilmesinde yerel demokrasi kademesine özel bir önem yüklemektedir. Bu özel önem, her şeyden önce yerelde demokrasiyi gerçekleştirmenin nesnel koşullarının daha uygun olmasından kaynaklanmakta olup, ona göre yerel ölçek katılımcı demokrasi pratiklerine üst kademelerden daha açıktır (Tekeli, 2012, s.185). Yerel ölçekte gerçekleştirileceklerin demokratik yollarla belirlendiğini söyleyebilmek için bir yerel kamu alanının varlığı gerekli olup, topluluk için alınacak kararlar ancak yerelde rasyonel bir müzakere sürecine dayanılarak alınıyorsa kararın demokratik olduğu kabul edilecektir (Tekeli, 2004b, s.35). Böylesi bir kamusal alanda tartışılmaksızın alınan kararlarsa demokratik olarak kabul görmeyecek ve seçimle gelmiş olmak da 
kararı demokratik kılmaya yetmeyecektir. Yerel kamusal alanlar, bu anlamda insanların bir araya gelerek kendilerini ilgilendiren meseleleri özgürce müzakere edip karara bağladıkları, birbirlerini düşünceleriyle etkileyebildikleri mekânlardır (Tekeli, 2009d, s.229-231).

Böyle bir yerelin üyeleri aktif sorumluluk alabilen bireyler olup, çözümleri başkalarından beklemeyen, himayeci siyasal pratiklere bel bağlamayan bireylerdir. Bu bireylerden oluşan yerel topluluklar da geçmişteki yerelden niteliksel olarak farklı olup, insanların yaratıcılıklarını, özgürlüklerini besleyen, bireyleri silikleştirmeyen, baskılamayan, tek tipleştirmeyen, çoğulcu, farklılıklardan birliği türetebilen, çeşitliliği zenginlik olarak gören, yeniliklere imkân tanıyan bir topluluk olacaktır (Tekeli, 2009e, s.227; 2017, s.128).

Yerel kamu alanının işleyişinin demokratik olması adına yerel kamusal alanda karşılıklı etkileşime imkân vererek bireyin özgür iradesinin oluşumuna olanak tanıyan STK'ların da gelişmiş olması gerekir. Bu örgütlenmelerde katılımı ve bireylerin sorumluluk üstlenmelerini mümkün kılabilmek ve yaratıcı gücü harekete geçirebilmek için hiyerarşik ilişkilerden kaçınılmalı ve yatay örgütlenilmelidir. Yine örgütlenmenin gönüllü olması, bu bağlamda konu ile ilgili olanların katılımına açık, ilgisi azalanlarınsa ayrılabilmelerine izin veren bir yapı olması gerekir (Tekeli, 2017, s.197). Tekeli STK'ların yanı sıra yerel kamusal alanda temsili demokrasinin daha katılımc bir şekle evrilebilmesi için, ikinci Habitat Konferansı hazırlıkları esnasında kullanılan ve benimsenen koza kavramına atıfla, iki tür kozanın oluşturulabileceğini söylemektedir. Bu kozaların bir kısmı mahalle kozaları, diğerleriyse o yerde yaşayanların sorunlarıyla ilgili oluşturulacak özel kozalardır. Soruna özgü kurulan kozaların, mümkün olduğu ölçüde kendi ilgi alanları dışına çıkmamasına özen gösterilmeli ve yeni oluşan sorunlar için yeni kozalar oluşturulmalıdır. Kozalarda yurttaşlar, ilgili özel ve kamu kuruluşları temsilcileri bir araya geleceklerdir. Yatay ilişkilerin egemen olduğu alanda kozaların içindeki ve kozaların arasındaki ilişkiler eşitler arası ilişkiler şeklinde gelişecek ve kozalar, toplumda gerekli gördükleri tüm aktörle yatay ilişkilere girebileceklerdir. Tekeli'nin düşünce sistematiğinde birer sivil toplum kamu alanı olarak görülen kozaların, sivil toplumun çalışma ahlakına uygun hareket etmeleri gerekmektedir. Bu çerçevede kozalar, yerel siyasal aktörlerin kendilerini sergiledikleri alanlara dönüştürülmemeli ve katılımcılar buralara siyasal kamu alanının davranışlarının taşınmasına izin vermemelidirler. STK-yerel yönetim ortaklığında siyasi aktörler, kozalardaki çalışmalardan kozaları siya- 
sallaştırmayı beklememelidirler. Bu, yani siyasal kamu alanının alışkanlıklarının kozalara sirayet etmesi, kozaları tahrip edecektir (Tekeli, 2012, s.176-177; 2009e, s.228).

Tekeli'nin temsili demokrasinin katılıma demokrasiyle bütünleşmesi adına yukarıda özetlenerek verilen dört önerisi oldukça önemlidir. Bu dört öneriye ilaveten Tekeli Türkiye'de demokrasinin istenen biçimde çalışmamasının temel nedenini de bu öneriler üzerinden anlam kazanacak biçimde ortaya koymaktadır. Ona göre, “Türkiye'de yerel bir siyaset alanı tanımlanmış olmasına karşın bu siyaset alanına tekabül eden bir kamusal alan örgütlenmemiştir". Yani içinde işlerin ne şekilde gerçekleştirileceğinin müzakere edildiği, eleştirel ve rasyonel tartı̧manın sürdüğü bir kamusal alan bulunmamaktadır. Oluşabilen yerel kamusal alanı da merkezi siyaset işgal etmiş durumdadır. Eğer işler bir demokrasi geliştirecekse, alanın merkezin işgalinden temizlenmesi gerekmektedir (Tekeli, 2009d, s.230; 2012, s.220). Diğer taraftan da Türkiye'de yerel yönetimler, mal ve hizmet üretme fonksiyonlarıla anlam kazanmakta ve yerelin bir katılım alanı olduğu çoğu kez unutulmaktadır. Öte taraftan da yurttaşlık bilincinin gelişmesini engelleyen ve himayecilik kanalıyla işleyen ağlar içinde yerel birimlerce üretilen mal ve hizmetlerin tüketicisi olmakla sınırlandırılmış rolleriyle yerel halka da hemşehri oldukları unutturulmaktadır (Tekeli, 2012, s.205).

Yerel kamu alanın merkezi siyaset tarafindan tamamen işgal edilmiş olması Tekeli'ye göre biri "yerel siyaset pratikleriyle yerel kamu alanları arasında sağlıklı bir ilişkinin nasıl kurulacağı" diğeri ise "kamu alanının onu işgal etme ve sağllksızlaştırma girişimlerine karşı nasıl korunacağı" olmak üzere iki soru üzerinde düşünmeye zorlamalıdır bizleri (Tekeli, 2009d, s.232). Kanaatimizce bu sorunun yanıtı bir taraftan işler bir yerel kamu alanının varlığını diğer taraftan da genel anlamda daha iyi işleyen bir demokrasinin nasıl inşa edilebileceğinin yanıtını da içermektedir. Sorunun yanıtını Tekeli'den hareketle vermek gerekirse; merkez ile yerel arasında sağlıklı bir ilişkinin kurulabilmesi ve yerelin merkezi siyaset tarafından işgal edilmemesi adına ortaklığın yerel yöneticiler için bazı yetkilerin bölüşülmesi anlamına geldiği, yerel halk için de sorumluluk üstlenmek anlamını taşıdığı unutulmamalıdır. Taraflardan her ikisi de bu bilinçle hareket ederek, bu ilişkinin siyasallaşıp bir himayecilik ilişkisi halini almasına müsaade etmemelidir. Siyasetçilerin de bu ilişkide umdukları tek şey yönettikleri yerlerde demokrasinin iyi işlemesine katkıda bulunmaktan başka bir şey olmamalıdır. Eğer bir yerel yönetici, her 
şeyi en iyi kendisi bildiği yanılgısına sahip değilse ve kamu yararını önceleyerek hareket eden demokrat bir kişiliğe sahipse yerel kamu alanı onun için bir tehdit değil bilakis onun en önemli gücünü oluşturacaktır.

\section{Sonuç}

Tekeli günümüzde temsili demokrasilerin bir kriz içine girdiğini kabul etmekle birlikte, demokrasinin yeni formu olarak kabul gören katılımcı demokrasinin temsili demokrasiyi bütünüyle yerinden edemediğini düşünür. Bunu katılımcı demokrasinin yetersizliklerine dayandıran Tekeli, katılımcı demokrasiye içkin anarşist eğilimlerin sistemin kendi kendini üretmesine engel teşkil edebileceğini ileri sürer. Ona göre sistem bunalıma girdiğinde müdahale yönteminin nasıl belirleneceğine ve bireylerin yaşam projelerini gerçekleştirirlerken uyacakları kuralların nasıl geliştirileceğine katılımcı demokrasi yanıt üretmekten uzaktır. Katılımcı demokrasinin bu yetersizliği halinde bu gereksinmeyi sağlayacak bir ulus devlet ve temsili demokrasi de varlığını koruyacaktır. Ancak kaçınılmaz olarak temsili demokrasi de kendi meşruiyeti yanı sıra katılımcı demokrasi pratiklerine de büyük ölçüde yer açmak durumunda kalacaktır. İki demokrasi anlayışının birlikte var olabilmesi ise büyük ölçüde kamusal bireyi geri getirecek sivil toplum kuruluşlarının ve yerel demokrasinin varlığına dayalı görünmektedir. Bu bağlamda Tekeli'nin fikirlerinden hareket edilecek olursa Türkiye'de demokrasinin temsili demokrasinin kısıtlarından kurtulup daha katılımcı bir hal alması isteniyorsa, merkezi siyaset tarafından işgal edilen sivil toplum ve yerel kamusal alanın işgalden kurtarılarak asıl ahlaklarına uygun bir şekilde işler kılınması gerektiği belirtilmelidir. 


\section{Extended Abstract}

\section{Civil Society Organizations and Local Governments as a Response to Crisis of Representative Democracy within the Thoughts of İlhan Tekeli}

\author{
Hülya Eşki Uğuz \\ ORCID: 0000-0003-1583-0501
}

\author{
Firat Harun Yilmaz \\ ORCID: 0000-0003-2838-5400
}

Eroding in the foundations of representative democracy and its crisis of legitimacy leaves us facing the problem of developing a new practice of democracy that is appropriate for the new reality in the spatial organization of the world and capable of fulfilling the expectations of individuals. In the understanding of Tekeli, who has written works on the course of this new democracy practice, civil society organizations (CSOs) have a distinct place in line with today's reality, in other words in making democracy more democratic. His understanding of CSOs as a public sphere transforms political power in a consensus. In this case, a structure emerges in which two different power coexist. One is a political power that gains its legitimacy from the representation mechanism and the other that owes the validity of its existence to the consensus among a large number of small public spheres. On one side of this power relationship, CSOs do not claim to cover the whole public sphere. They claim to co-exist with political power, enrich the public sphere and thus to realize pluralism. From this point, it cannot be said that the qualitative and quantitative development of CSOs eliminates the need for political power. If there is no political public sphere and a public authority based on it, CSOs will not be able to perform the function expected from them. For this reason, civil and political public spheres need to coexist. In this way, the quality of democracy can be enhanced and generate certain desired results. After he laid out the necessity for both public spheres to coexist, Tekeli makes important inferences about the position of political and civil society public spheres relative to each other. According to him, the morals of political and civil society public spheres must be different from 
each other. In contrast, the morals of the political sphere which is tense, based on the practice of organizing in opposition to the other rather than consensus in this sense also exclude others-, the civil sphere is not dominated by a confrontational morality. On the contrary, the power in this sphere derived from consensus.

In Tekeli's consideration, which indicates that the integration of representative democracy with participatory democracy will efficiently take place in the local area, a special emphasis is placed on the level of local democracy. Accordingly, to mention of the local democracy, certain local public sphere needs to exist. The decisions to make will only be considered democratic if they are based upon a rational negotiation process. Members of such locals are individuals who can take active responsibility, do not expect solutions from others and do not rely on patronizing political practices. On behalf of the democratic functioning of the local public sphere, CSOs that ensure the formation of the free will of the individual by enabling interaction in the local public sphere also need to be developed. Besides CSOs, for representative democracy to evolve into a more participatory form in the local public spheres, Tekeli addresses the cocoon-style organizations, some of which are neighborhood cocoons and others are specific cocoons to be created for the problems of those living in a certain place. The cocoons which are seen as civil society public spaces in Tekeli's understanding should act in the work morals of civil society. Within this framework, cocoons should be transformed into areas where local political actors present themselves and participants should not allow bringing the actions of the political public sphere to cocoons.

This study generally based upon the writings of Iilhan Tekeli -outlined above- on "representative democracy", "participatory democracy", "active citizens", "civil society organizations" and "local governments". In the study, it was tried to indicate what Tekeli's response to the crisis of representative democracy is. While searching this response, CSOs were reached out from the inefficacy of representative democracy and the development of the notion of participatory democracy. On the other side, local governments as the best practice level in making the performance of democracies satisfactory with participation were addressed. It is thought that such a re-reading has the power to answer questions about why democracy is problematic in Turkey and how it can function more effectively. 


\section{Kaynakça/References}

Tekeli, İ. (1997). Sivil toplum örgütleri ve yerel yönetimler. Ankara: Türk Belediyecilik Derneği ve Konrad Adenauer Vakfı Yayınları.

Tekeli, İ. (1999). Modernite aşllırken siyaset. Ankara: İmge Kitabevi.

Tekeli, İ. (2000). Gelişen ve saygınlı̆̆ıı koruyabilen bir toplum alanının oluşma koşulları üzerine düşünceler. Tekeli, İ., (Ed.), Yasalar-etik-deprem ve sivil toplum kuruluşları içinde. (s. 111-115) İstanbul: Tarih Vakfı Yurt Yayınları.

Tekeli, İ. (2002). STK'lar, yerelleşme ve yerel yönetimler sempozyumu açıllş̧ konuşması. Çamak, A, (Ed.), STK'lar, yerelleşme ve yerel yönetimler içinde (s. 5-26). İstanbul: Tarih Vakfı Yurt Yayınları

Tekeli, İ. (2004a). Tek ve kademeli demokrasi kurumlarının ontolojik kabulleri üzerine. Doğu Batı Düşünce Dergisi, 28, 195-225.

Tekeli, İ. (2004b). Yerel siyaset, demokrasi ve sivil toplum. Kent Gündemi, 6, 33-36.

Tekeli, İ. (2006). Türkiye'de sivil toplum kuruluşlarındaki gelişmeler ve regülasyon sorunları. Tekeli, İ, (Ed.), Katıılımcı demokrasi ve sivil toplum kuruluşları içinde. (s. 137-156) Ankara: Sosyal Demokrasi Derneği Yayınları.

Tekeli, İ. (2007). Onurlu bir yaşam için yeni bir siyaset yapma biçimi. İstanbul: TÜSES Yayınlarn.

Tekeli, İ. (2009a). Bir demokrasi projesi olarak yerel habitatlar. Tekeli, İ, (Ed.), Akılcı planlamadan, bir demokrasi projesi olarak planlamaya içinde. (s. 208-220) İstanbul: Tarih Vakfı Yurt Yayınları.

Tekeli, İ. (2009b). Küreselleşen ve moderniteyi aşan dünya artık temsili demokrasiyle yetinemiyor. Tekeli, İ, (Ed.), Akılci planlamadan, bir demokrasi projesi olarak planlamaya (s. 233-245) içinde. İstanbul: Tarih Vakfı Yurt Yayınları.

Tekeli, İ. (2009c). Bir demokrasi projesi olarak kent planlama. Tekeli, İ, (Ed.), Akılcı planlamadan, bir demokrasi projesi olarak planlamaya içinde (s. 311-327). İstanbul: Tarih Vakfi Yurt Yayınları.

Tekeli, İ. (2009d). Yerel demokrasi için kamu alanı oluşturmak gerekir. Tekeli, İ, (Ed.), Akılcı planlamadan, bir demokrasi projesi olarak planlamaya içinde. (s. 229-232) İstanbul: Tarih Vakfı Yurt Yayınları.

Tekeli, İ. (2009e). Artık yurttaşlk bilgisi kitabina hapsolamayan yurttaşlk sorunu. Tekeli, İ, (Ed.), Akılcı planlamadan, bir demokrasi projesi olarak planlamaya içinde (s. 221228). İstanbul: Tarih Vakfi Yurt Yayınları.

Tekeli, İ. (2011). Türkiye için siyaset ve demokrasi yazıları. İstanbul: Tarih Vakfi Yurt Yayınları.

Tekeli, İ. (2012). Türkiye için STK'lar ve katıllmo demokrasi yazıları. İstanbul: Tarih Vakfı Yurt Yayınları.

Tekeli, İ. (2017). Katıllmoı demokrasi ve sivil toplum kuruluşları. Ankara: Sosyal Demokrasi Derneği Yayınları. 